\title{
Cativas do corpo, libertas pelo trabalho: casos de mulheres de cor nas fronteiras entre escravidão e liberdade (Mariana, séculos XVIII e XIX) ${ }^{*}$
}

\author{
Fernanda Domingos Pinheiro** \\ Ludmila de Souza Maia***
}

\section{Resumo}

Neste artigo, analisamos a influência dos corpos das mulheres de cor, suas sexualidades e seus trabalhos na conquista e no usufruto da liberdade. Com base em ações cíveis produzidas pelo tribunal colonial de Mariana, em Minas Gerais, observamos como o fato de ser mulher foi fator limitante ou de risco para a manutenção da autonomia de alforriadas, coartadas ou nascidas de ventre livre. Mas, por vezes, sobressaem desses litígios os modos como elas conseguiram tirar proveito de seu gênero ao firmar arranjos favoráveis a si como o rompimento de antigos elos de dependência.

Palavras-chave: Mulheres de cor, Escravidão, Liberdade, Justiça.

\footnotetext{
Recebido para publicação em 18 de novembro de 2015, aceito em 3 de março de 2017.

** Professora adjunta do Instituto de Humanidades e Letras, Universidades da Integração Internacional da Lusofonia Afro-Brasileira (UNILAB), Redenção-CE, Brasil. fernandapinheiro@unilab.edu.br
}

*** Pesquisadora associada, em nível de pós-doutorado, em Rice University, Houston-TX, Estados Unidos. ludmilasouzamaia@gmail.com 
Captives of The Body: Cases of Women of Color in The Boundaries between Slavery and Freedom (Mariana, XVIII and XIX Centuries)

\begin{abstract}
In this article, we analyze how the bodies, the sexuality, and the labor of women of color influenced the acquisition of their manumission and the enjoyment of their free status. Based on lawsuits from the Colonial Court in Mariana, Minas Gerais, we discuss how being a woman was a constraint, or risk factor for those who had to face obstacles to keep their autonomy as coartadas, freed or free-born women. At the same time, in these legal processes also emerged their strategies to take advantage of their gender in order to defend their own interests, such as for instance the breaking of old ties of dependence.
\end{abstract}

Keywords: Women of Color, Slavery, Freedom, Court Lawsuits. 
Doña Antonia, de cuarenta y cinco años de edad, infértil, explicó que sabía de los usos que su esposo le daba a la esclava. Que los oía refocilándose por todas partes, su esposo bufando sobre el cuerpo de la esclava y que, más de una vez, los había visto "en el acto"(Fe en Disfraz. Mayra Santos-Febres).

\section{Introdução}

$\mathrm{Na}$ sociedade colonial, os escravos estavam sujeitos à mercantilização de seus corpos, entendidos como propriedade para exploração do trabalho. Tal exploração, entretanto, não se deu da mesma forma para homens e mulheres. Além da idade e das habilidades manuais, o gênero dos cativos, estando ou não aliado à personalidade e às características físicas, definiu em grande medida seus destinos. Por conseguinte, as experiências no cativeiro foram diversas (Mott, 1988:18). E, como enfatizaremos neste artigo, o mesmo se pode dizer sobre a influência do gênero em relação às vias de acesso à alforria, de usufruto e manutenção da liberdade. Ser mulher é um dado importante para enriquecer nossa compreensão a respeito dos processos de libertação, das possibilidades de desfrute e perda do estatuto de alforriada como, já de início, evidencia a história de Josefa de Moraes. ${ }^{1}$

A crioula ${ }^{2}$ residente na cidade de Mariana, capitania das Minas Gerais, foi chamada a responder perante o juiz uma ação

\footnotetext{
1 Neste artigo, escolhemos utilizar o nome próprio das partes envolvidas no processo. O uso do nome, em vez do sobrenome, nos ajuda a distinguir o gênero dos indivíduos e a evitar confusão com os sobrenomes portugueses, que na maioria das vezes, se repetem. Ainda que Linda Colley (2007:XXIX) tenha defendido que o nome próprio infantiliza as mulheres protagonistas em pesquisas de História, no nosso caso, optamos por chamar homens e mulheres pelo primeiro nome apenas com a intenção de facilitar a leitura do texto.

2 No caso brasileiro, o termo é frequentemente utilizado para indicar os descendentes de africanos, nascidos na América portuguesa ou no Brasil Império.
} 
cível de reescravização ${ }^{3}$ depois de abandonar a casa de José de Moraes e Sá (Arquivo Histórico da Casa Setecentista de Mariana $2^{\circ}$ Ofício, Ações Cíveis, Códice 275, Auto 6760). Ele moveu um libelo ${ }^{4}$ em agosto de 1761, com a intenção de provar que Josefa era sua escrava e devia retornar ao seu domínio. Para tanto, alegou que "estando (...) de posse da ré, ela se ausentou de casa, $e$ entrou a publicar que era forra sem na verdade ser, nem ter título que [fosse] justo, ou válido". Em sua defesa, Josefa logo exibiu em Juízo sua alforria, uma carta particular - escrita $e$ assinada por José, em 26 de fevereiro de 1756 - que fora registrada em cartório por iniciativa dela própria, depois que saíra da companhia daquele que considerava ser seu ex-senhor. Ela era, conforme sua versão, uma preta forra que, para viver a liberdade outorgada na carta de alforria, precisou fugir de madrugada.

Numa tentativa desesperada ou há muito planejada, ela pôs fim ao antigo vínculo de dependência que remontava à época em que era escrava do pai do litigante. Seu rompimento abrupto é prova de que esse não era o comportamento esperado, nem tampouco aprovado. Às mulheres alforriadas, o espaço de autonomia era frequentemente negociado no âmbito das relações domésticas. Delas esperava-se, em especial, que permanecessem sob o controle dos ex-senhores, como criadas, servindo para manter o elo de submissão dos seus descendentes (Machado, 2010:161; Cunha, 1986:132-133). Contrariando tais expectativas e a vontade patronal, Josefa deixara a companhia de José por desejar desfrutar plenamente do novo estatuto jurídico, mas a causa direta da sua fuga foi ocultada pelo advogado da preta forra. Reiteradamente, ele declarou que "em virtude do mesmo papel [de alforria] que [era] o título que tinha, [Josefa] se ausentou da

3 São processos judiciais movidos com o objetivo de puxar de volta ao domínio senhorial alguém que já vivia fora do cativeiro. Sobre essa prática no período colonial, ver Pinheiro (2013).

${ }^{4}$ O libelo cível era um tipo de processo de tramitação ordinária (Título 20, Livro 3 , das Ordenações Filipinas). Era, portanto, uma forma processual mais recorrente e detalhada e, por isso, poderia ser de curso mais demorado. 
casa do Autor [José] por várias circunstâncias que por honestidade se cala[va]m".

O silêncio, porém, foi quebrado pela crioula em seu depoimento. De início, seguindo o exemplo do seu advogado, ela apenas afirmou que após receber a alforria, continuou na companhia de José que se "servi[a] dela depoente no serviço de sua casa e ainda de outras coisas que por modéstia [se] cala[va]". Calada Josefa continuou até ouvir a alegação do patrono de que ela não teria sido libertada por não ter tido meios de pagar o preço da sua alforria (239\$000 réis). Foi então que Josefa revelou

que o autor [José] recebeu da mãe dela depoente a quantia que declara o papel de liberdade (...) e, suposto o mesmo autor $\operatorname{diz}[e r]$ não recebera ouro, contudo recebeu da mãe dela depoente muitos anos de serviço por aquela lhe estar a trabalhar em todo o gênero dele, tanto do governo de sua casa, como ainda de outros que se lhe oferecia e em razão disto de haver o mesmo autor (...) anda[do] amancebado com ela depoente foi o motivo por que lhe passou a carta de alforria que é a própria de que se trata, nem o autor querendo falar a verdade, disse apaixonado do ódio que de presente tem a ela depoente causado de se lhe não querer mais sujeitar...(AHCSM $-2^{\circ}$ Ofício, Ações Cíveis, Códice 275, Auto 6760, fl. 51).

Conforme sua declaração, a quantia registrada no papel de manumissão como pagamento pela libertação representava os serviços prestados por sua mãe e os préstimos carnais exigidos por José desde que Josefa tinha "12 ou 13 anos de idade"; e que continuou exigindo depois de a crioula tomar o estado de mulher casada e de ex-escrava. ${ }^{5}$ Desprezando a nova circunstância, o

\footnotetext{
${ }^{5}$ As ex-escravas americanas, Sojourner Truth e Harriet Jacobs, relataram, quase cem anos depois, que havia pouca margem de manobra para o assédio vindo de um homem branco. Jacobs conta que aceitou ser amante de um homem branco como um "cálculo deliberado", pois pensava que ele poderia melhorar sua condição degradante e as circunstâncias opressivas de sua vida. Ao mesmo tempo, a recusa em ceder ao assédio resultaria em castigos físicos cruéis. Ver Washington (2007:64).
} 
patrono ${ }^{6}$ ainda a perseguia para manter relações sexuais. E "para quitar a ocasião" dos ataques, Josefa precisou finalmente se afastar e fazer valer a carta de alforria que tinha em seu poder havia alguns anos.

Sem perder de vista a intenção de José de conduzir novamente Josefa ao cativeiro, impressiona um tanto mais a descrição dos fatos que sustentavam a confissão do abuso sofrido por tanto tempo. Josefa afirmou ainda que seu casamento com um escravo resultou da pressão exercida pelo pároco da freguesia de Antônio Pereira que sabia da mancebia dela com o senhor. José havia arrumado tal matrimônio para escapar da repressão eclesiástica e assegurar, de forma dissimulada, a manutenção da crioula como sua concubina. ${ }^{7}$ Certamente, ao tomar essa decisão, ele havia calculado que a união conjugal, ao criar uma obrigação moral entre os cônjuges, seus escravos, reforçaria a manutenção de Josefa sob seu domínio. ${ }^{8}$ Por isso concedeu a alforria de Josefa após o enlace. Sua libertação, por outro lado, poderia ter servido para lhe compensar o constrangimento de um casamento forçado e também para alcançar dela gratidão, sentimento capaz de fazer com que continuasse a saciar a concupiscência do seu ex-senhor.

Sendo assim, a exploração do corpo de Josefa, para além da exploração do seu trabalho, foi fator determinante para que a crioula deixasse de ser escrava e se tornasse forra. Mas isso não basta para resumir toda a sua experiência. Antes é preciso ressaltar

${ }^{6}$ Patrono é o modo como era designado o ex-senhor. O termo representa o laço de dependência que mantinha o ex-escravo vinculado ao indivíduo que lhe concedera a alforria.

${ }^{7}$ Há um paralelo interessante com a escravidão no mundo muçulmano que nos foi gentilmente apontado pelo professor Dr. Jean Philippe Belleau, em um debate durante o Congresso LASA 2015. Ver Sreenivasam (2006:136-161).

8 O senhor José, ao casar Josefa com um de seus escravos, aumentava a dependência de Josefa em relação a si, já que ela deveria permanecer junto ao esposo. A inseparabilidade dos casados era uma das finalidades de uma união sacramentada pela Igreja e, como tal, prevista nas Constituições Primeiras do Arcebispado da Bahia - Leis disciplinares da Igreja produzidas no Sínodo Diocesano de 12 de junho de 1707. 
o seguinte: se de um lado o trato ilícito com o ex-senhor lhe facultou a alforria, de outro lado, lhe induziu a ficar "debaixo do domínio" do patrono amante, sujeita às suas vontades $e$ determinações. Desse modo, seu estatuto jurídico foi alterado, mas seu corpo continuou objeto do desejo e de consequente submissão. Josefa esteve impedida de desfrutar da autonomia que lhe fora concedida na carta de alforria. E nisso, outros fatores contribuíram. Além do vínculo conjugal com um escravo de seu patrono, Josefa era só uma mocinha quando obteve sua alforria. $\mathrm{E}$, por vezes, sofreu enfermidades que a debilitaram ao ponto de ser enviada para tratamento em Vila Rica, à custa do patrono. Diante das novas informações, fica fácil entrever a vulnerabilidade que cercava a existência dessa mulher de cor, ainda jovem e, em algumas ocasiões, impedida de tratar do seu sustento.

Entre 1756 e 1761, Josefa continuou servindo a José nas mais variadas funções domésticas e "na cama". Do trato ilícito nasceu um filho. Em dezembro de 1760, ela deu à luz Manuel e foi coagida a abandoná-lo, visto "ser casada com um crioulo e haver parido mulato". Diante do nascimento de uma criança mestiça, ficou "receoso o autor [José] de que o marido dela depoente soubesse $e$ lhe fizesse algum absurdo" $e$, por esse motivo "implorou a ela depoente para que enjeitasse" o filho. ${ }^{9}$ Ela obedeceu, ficando o menino na casa de um vizinho, onde era criado com o consentimento do patrono amante. Talvez em razão disso, a preta forra tenha resolvido, no início de 1761, dar um basta àquela situação de exploração. $\mathrm{O}$ enjeitamento do filho poderia ter-lhe encorajado a fugir, valendo-se da alforria que detinha em mãos havia quatro anos. Também é possivel que naquele momento, ela tenha já conseguido enfrentar ou superar alguns dos fatores que contribuíram para que permanecesse sujeita às vontades e determinações de José.

\footnotetext{
9 Ao que parece, o marido de Josefa era descendente de pais africanos e, portanto, homem preto, que com ela, também preta, não poderia ter um filho mulato, ou seja, um mestiço.
} 
Certo é que para experimentar uma nova vida em liberdade, longe do governo do seu patrono, Josefa contrariou a obrigação de se manter ao lado do marido escravo, abdicou da "assistência" recebida em momentos de maior fragilidade e pôde, enfim, refutar as "perseguições" sexuais. Contudo, precisou enfrentar a fúria de José que visava, de todo jeito, reavê-la. Nesse novo contexto, era a manutenção da alforria e da autonomia recém-conquistada que estavam em risco. Mas, na instância jurídica, esse esforço foi anulado com o depoimento da crioula. Após relatar sua versão dos fatos, os autos foram abandonados. É provável que diante do que fora dito, José tenha preferido preservar suas relações pessoais de maior exposição pública. Com esse desfecho, Josefa teria escapado do litígio. Isso, porém, não era uma garantia de que estaria isenta de novas vexações na Justiça ou mesmo fora dela. Como veremos, muitos foram os riscos $e$ as ameaças de reescravização que incidiam sobre as mulheres de cor residentes no termo de Mariana, ao longo dos Setecentos e nas duas primeiras décadas do século XIX. E cabenos ainda compreender a influência das relações de gênero nesses processos de redução ao cativeiro, bem como na conquista da alforria. E mais do que isso, perceber como esses casos revelam os limites $e$ as possibilidades de seu uso, ou apropriação, pelas próprias mulheres de cor em Mariana colonial.

Recentemente, muitos estudiosos vêm analisando as mulheres $e$ as relações de gênero na História do Brasil $e$, especificamente, nos séculos de sua colonização (Algranti, 1993; Mesquita, 2003; Dias, 1984; Del Priori, 1993; Silva, 1998, 2002). Encontradas em grande número nesse cenário, as africanas $e$ crioulas, escravas e libertas, também alcançaram visibilidade em importantes obras historiográficas. Entre os alforriados, as mulheres ganharam papel de destaque porque sobrepuseram numericamente os homens, contrariando a estrutura demográfica de várias localidades (Gonçalves, 2011:186-187). Segundo Luciano Figueiredo (1993) e Carlos Eugênio Soares (2001:401-415), muitas escravas souberam aproveitar a autonomia decorrente do trabalho nas ruas para acumular o pecúlio que aplicavam, quando possível, 
na compra de suas alforrias; ou fizeram uso da mobilidade física que desfrutavam para tecer e acionar indivíduos em suas redes de sociabilidade que, por vezes, financiavam a libertação.

Diante de tais percepções, as libertas despertaram a curiosidade de muitos pesquisadores que se debruçaram sobre séries de testamentos e inventários post-mortem, com a finalidade de entender como elas conseguiram sobreviver e angariar recursos que, mais tarde, distribuíram entre seus herdeiros. Grande interesse recaiu (e continua incidindo) sobre as atividades com as quais essas mulheres se ocupavam, o poder econômico que detinham, a estrutura familiar que organizavam, as casas onde moravam, os objetos que possuíam, entre os quais, examinou-se, sobretudo, o perfil da escravaria reunida. Especial atenção se deu ao modo como elas transformaram seus pertences em legados e à seleção que fizeram dos herdeiros (Faria, 2001; Oliveira, 1988; Paiva, 2001).

Devemos admitir que tendo essas mesmas preocupações $e$ diferentes campos de observação, os historiadores chegaram a algumas conclusões divergentes, mas, em grande parte, igualmente ressaltaram as possibilidades de ascensão econômica $e$ consequente distinção social das africanas e crioulas alforriadas. Tomados em conjunto, tais estudos enfatizaram a agência das libertas, como aqueles que trataram da participação das mulheres no pequeno comércio e nas escrituras de alforria como beneficiadas. Abordando estratégias vitoriosas de sobrevivência, as renovadas pesquisas superaram a perspectiva generalizante de crueldade da escravidão intrínseca à exploração econômica $e$ sexual; enfim, as escravas e forras emergiram dos documentos como agentes históricos capazes de enfrentar e vencer a opressão característica da ordem escravista (Furtado, 2001).

Isso, contudo, não encerra a questão. Se, por um lado, a agência das mulheres de cor rompeu com o estigma da vitimização, por outro, contribuiu para escamotear a violência presente nas relações sociais. Querendo impedir que uma imagem fixa de superação substitua a da figura vitimizada, não podemos nos esquivar de considerar os maus-tratos e coerções que viveram 
escravas e libertas para observar situações que ainda escapam, com frequência, das lentes dos historiadores. Inegavelmente, o corpo da mulher negra experimentou a escravidão de modo diferenciado; elas, por exemplo, estavam muito mais suscetíveis a sofrer abusos sexuais e muitas delas experimentaram severas agruras. Algumas, entretanto, conseguiram escapar, enquanto outras transformaram as agressões em instrumento de defesa de seus interesses. Entre uma realidade e outra, nos interessa aqui o movimento possível entre ambas as situações extremas, observando as possíveis funcionalidades da violência sofrida pela mulher de cor, inserida na sociedade escravista colonial. Para elas, sofrer abusos serviu tanto para conquistar e usufruir como também para restringir a liberdade, conforme ilustra o caso de Josefa de Moraes. Lidar com essa dualidade torna-se, portanto, nosso maior desafio.

Com esse intuito, gênero é aqui pensado a partir da clássica definição de Joan Scott (1995:71-99), ainda importante para pensar casos como os das mulheres negras cujas experiências se situam entre a escravidão e a liberdade. Segundo a autora, gênero é uma categoria de análise histórica constitutiva das relações sociais, fundamentada nas diferenças entre homens e mulheres, ao mesmo tempo em que é também uma fonte primeira de conferir significados às relações de poder (Scott, 1995:71-99; Soihet, 1997:95-114). Tal definição também contribui com nossa análise por realizar articulações com outras categorias analíticas como raça, classe e geração. Ao interpretar casos de disputa judicial em torno da liberdade de um grupo de mulheres de cor de Mariana colonial, procuramos entender como as relações de gênero funcionavam nesse contexto histórico específico, pois defini-lo a partir de uma ideia transcendental nos levaria a um essencialismo (Wildenthal, 2001:10).

Cabe ainda ressaltar que recorremos também à categoria "mulher". Não consideramos, porém, que essa seja categoria homogênea ou unívoca e, de alguma maneira, que seja determinada pela fisiologia dos corpos. Ao contrário, nosso objetivo ao empregar o termo mulher é recriá-la como um agente 
histórico fundamental, privilegiando suas diferenças $e$ semelhanças, bem como seus protagonismos individuais (agency) (Nicholson, 2000:9-43; Piscitelli, 2001; Davis, 1997; Dias, 1995; Perrot, 2005, 2007). Nós buscamos observar as experiências e intenções dessas mulheres em rejeitar ou se adequar às regras sociais de seu tempo, assim como seus modos de se relacionar com o mundo de sua época (Anagol, 2005:10). A abordagem ao sujeito feminino empreendido por Natalie Davis, Nas Margens (1997), nos ajudou a pensar como as experiências dessas alforriadas ou livres de cor distanciaram-se das experiências de homens negros e libertos que também litigaram pela manutenção, restituição ou usufruto de suas liberdades. Nosso objetivo é perceber como a opressão de gênero particularizou suas vivências, ao mesmo tempo em que lhes conferiu brechas ou possibilidades de obter vantagens nessa situação de marginalidade e maior vulnerabilidade.

\section{A. A maternidade e o trato ilícito - cativas do corpo}

A leitura de algumas disputas judiciais travadas ainda durante o período colonial demonstra que nem a alforria, nem o fato de ter nascido de mãe forra ou livre de cor, garantiu a vivência dos africanos e seus descendentes fora do cativeiro. A reescravização era uma prática naquela sociedade e, por certo, atingiu ou afligiu parte da população liberta. Reconhecendo a importância de tal fenômeno, sobre ele foram localizadas algumas dezenas de processos autuados em Mariana, ao longo do século $\mathrm{XVIII} e$ nas duas primeiras décadas do século XIX. ${ }^{10}$

Desse conjunto documental, sobressaem os conflitos que giraram em torno de casos de mulheres negras, dos quais pretendemos aqui examinar minuciosamente os que mais chamam nossa atenção, em razão da riqueza de informações registradas nos depoimentos, testemunhos, argumentos

\footnotetext{
${ }^{10}$ Mais especificamente, no Arquivo Histórico da Casa Setecentista de Mariana foram encontrados 89 ações cíveis que tiveram como objeto de disputa a reescravização, incluindo tanto as demandas para se proceder sua execução, quanto as oposições a seu risco ou a sua real concretização.
} 
empregados em defesa das partes litigantes e, principalmente, pelas questões de gênero neles presentes. Os processos das mulheres escolhidas para compor este artigo, fossem excepcionais ou representativos de sua época, são capazes de revelar questões mais gerais sobre as expectativas e restrições experimentadas pelas mulheres de cor em Mariana, ou mesmo por suas contemporâneas de outras localidades da colônia.

De modo geral, a experiência do cativeiro no caso das africanas e suas descendentes associava-se não apenas à exploração do trabalho no sentido clássico do termo (esforço físico e braçal nas minas ou no serviço doméstico, por exemplo), mas relacionava-se, sobremaneira, à sua função reprodutiva. Levavase em conta a sua capacidade de aumentar o número de escravos de um senhor e consequentemente seu patrimônio, ou de serem utilizadas para os trabalhos da intimidade ou no serviço de "portas adentro", tornando-se com frequência concubinas de homens livres - algo raro para o caso dos escravos homens (Machado, 2010:168).

Sem dúvida, a centralidade do ventre e a possibilidade da exploração sexual do corpo feminino influenciaram as trajetórias das escravas e, em certa medida, também impactaram na manutenção da liberdade de mulheres já alforriadas e das que se encontravam em vias de libertação. Em alguns casos, uma gestação poderia levar as libertas e coartadas ${ }^{11}$ à perda do estatuto ou usufruto da liberdade, devido ao interesse do senhor em se apossar da criança como seu novo escravo. Isto é o que podemos

\footnotetext{
${ }^{11}$ Coartada é a escrava que parcelava o preço da sua liberdade por um período determinado de tempo e negociava as condições para sua quitação. Ela, portanto, vivia a expectativa de se tornar forra após a satisfação do acordo firmado com seu senhor. A coartação era, frequentemente, registrada pelo senhor em carta particular - o papel de corte - que ficava sob a guarda da própria escrava coartada ou de seu fiador. Em seu verso eram inseridos os recibos das parcelas oferecidas e após completar o pagamento do valor total, o papel de corte poderia ser usado como título de liberdade e registrado em cartório com o mesmo intuito ou substituído pela alforria. É importante lembrar que a escrava coartada poderia já desfrutar de autonomia "como se forra fosse", dependendo da negociação firmada com o senhor.
} 
inferir a partir da história de Esméria. Em agosto de 1819, ela moveu uma ação cível contra seu suposto senhor, na qual denunciou, por meio de seu advogado e curador, a ilegalidade de sua escravidão (AHCSM - $2^{\circ}$ Ofício, Ações Cíveis, Códice 276, Auto 6787). Na petição que instaurou o processo foram descritas as circunstâncias do nascimento de Esméria, filha de Felícia, exescrava do réu, o senhor Francisco de Paula de Oliveira Vogado.

Em 1796, Felícia conseguira sua coartação com a condição de pagar 96 oitavas de ouro em três prestações - a primeira na ocasião em que o trato foi outorgado e as demais ao final de cada ano vindouro. Uma vez coartada, Felícia passou a viver como livre, indo "tratar de sua vida" e "gozando de sua liberdade". Ao final do primeiro ano, no entanto, o senhor e réu do processo a trouxe de volta ao cativeiro e rasgou seu papel de corte. Meses depois, estando na casa de Francisco, Felícia pariu Esméria. Nascida a rebenta no ano de 1797, o senhor refez o acordo de coartação por um valor mais baixo, usando a filha como moeda de troca e passando a Felícia novo corte. A mãe voltou a viver em liberdade, mas deixou a filha Esméria sob o domínio do referido senhor, que apesar de receber menos com a coartação de Felícia, havia lucrado mais com a posse da nova escravinha.

A menina era ainda muito jovem quando ficou órfã $e$ cresceu sem notícias dessa história, como consta no processo. Só pouco tempo antes de acionar a Justiça é que teve "quem lhe contasse a triste história de sua injusta escravidão". O conhecimento das circunstâncias de seu nascimento levou Esméria a exigir, na Justiça, a restituição da sua "liberdade natural" e a prerrogativa de assumir o estatuto jurídico de mulher livre, que lhe fora "injustamente" e "ilegalmente" usurpado. Assim foi argumentado em Juízo. Desse modo, rechaçou ainda a alcunha de liberta (ou ex-escrava), visto que sua mãe já desfrutava da condição de livre, graças à autonomia resultante do acordo de coartação que fora indevidamente revogado pelo réu. De acordo com sua versão, Esméria era filha de uma coartada que fora indevidamente reescravizada para que a parisse em cativeiro. Sua escravidão resultava, portanto, de um procedimento ilícito. Logo, 
sua escravidão era igualmente ilícita e ela se sentia no direito de ser resgatada dessa condição.

A história de Esméria, narrada diante do juiz marianense, aponta para um caso de ganância do senhor, que tendo coartado sua escrava, resolveu desfazer o trato quando soube de sua gravidez. Ao trazê-la novamente ao cativeiro, conseguiu ganhar a filha, tendo negociado, novamente, a liberdade da mãe após o parto.

A atitude de abuso de poder do senhor respaldava-se, ao menos, em duas coisas. A primeira dizia respeito à vulnerabilidade de Felícia. Apesar de ter recebido o papel de coartação e já viver fora do domínio senhorial, a mãe de Esméria acabou coagida por Francisco a retornar ao cativeiro, tendo ele usado a ameaça de ser ela apreendida por capitães do mato. Ora, se a ideia de ser caçado por capitães do mato era assustadora para qualquer cativo, podemos imaginar que o estado de gravidez avançada de Felícia agravou sua condição de vulnerabilidade, seja pelos temores de morte que a gravidez por si só já inspirava naquele momento, seja na dificuldade que tal estado a colocava, impossibilitando ou dificultando sobremaneira sua fuga ou resistência. Mulher grávida e ameaçada -, Felícia se viu constrangida a abandonar sua liberdade, ver desfeito seu trato de coartação e assistir ao nascimento de sua filha na ilegalidade de seu cativeiro.

A segunda razão para o abuso de poder senhorial relacionava-se à imprecisão do estado de coartado/a. Tornavamse livres os cativos logo feito o trato ou apenas após a compleição do pagamento? Embora não tenha existido uma normativa para tratar dessa prática na América portuguesa, o que percebemos é que a mudança do estatuto jurídico - de escravo para liberto - só ocorria após o pagamento total da coartação. No entanto, muitos escravos coartados já poderiam desfrutar da liberdade "como se forros fossem", dependendo das condições de autonomia negociadas com o senhor. Uma alteração da condição social poderia, portanto, ser anterior à mudança do estatuto jurídico. As implicações e as comprovações a esse respeito nortearam algumas das disputas arbitradas pelo tribunal de Mariana, nas quais 
poderiam ser beneficiados tanto senhores como escravos, observadas as especificidades de cada caso, bem como a praxe forense daquela localidade. Desse debate jurídico, no entanto, se isentou Francisco ao decidir que exerceria seu poder senhorial sobre Felícia, a fim de obter a posse de Esméria, a qual efetivamente manteve por cerca de 23 anos, até que sua autoridade foi contestada em Juízo.

Sobre a existência dessa contestação não temos dúvida, seu registro sobreviveu ao longo de muitos anos. Se a história é verídica já não podemos afirmar, mas era percebida na época como factível, tanto que foi contada com a finalidade de convencer um juiz. Essa presunção basta para chamar a atenção dos historiadores para a viabilidade da escravização ilegal da filha, e também para a situação da mãe, cuja vulnerabilidade permite constatar que o potencial de jovens coartadas para a maternidade colocava em risco a manutenção da autonomia já desfrutada e da própria coartação. Era grande o interesse dos senhores em utilizar os corpos dessas mulheres para a reprodução e consequente aumento da escravaria. Mas não só isso.

Os corpos das mulheres de cor também poderiam servir para saciar os "instintos" senhoriais. A relação sexual com uma coartada poderia ser ainda entendida pelos senhores como parte das suas atribuições, o que contribuía para a preservação dos laços de dependência. Não raro, exigia-se delas que o trabalho da lida doméstica fosse estendido também às atividades desempenhadas na intimidade da alcova. Assim Joaquim Vieira de Souza concebia o trabalho de Quitéria Maria Correa.

Quitéria era escrava de Antônio Corrêa Borges e sua mulher, residentes do Arraial do Calambau, $e$ foi dada como dote à filha do casal, dona Juliana Maria, na ocasião de suas núpcias com Joaquim Vieira de Souza. De acordo com Quitéria em um litígio que promoveu contra Joaquim, os dois tiveram um "trato ilícito" anterior ao casamento e, por esse motivo, ela acabou coartada pelo novo casal de senhores pelo preço de $192 \$ 000$ réis a 
ser pago em quatro anos e meio. ${ }^{12}$ A crioula, no entanto, pagou, aproximadamente, um quarto do valor total já nos primeiros seis meses, ficando "firme e valioso o contrato de liberdade como é deduzido de muitos doutrinadores".

Tudo parecia ir bem para os envolvidos nesse acordo até que ele foi desfeito. Joaquim dirigiu-se ao fiador da coartada, lhe exigiu o papel de corte que tinha em sua guarda e o rasgou na frente de diversas testemunhas; em seguida, vendeu Quitéria a João Severino Ventura, do Arraial do Piranga, onde a crioula serviu por 4 meses e meio. Apenas quando seu novo senhor decidiu vendê-la para "paragens não sabidas", Quitéria resolveu fugir e refugiar-se na casa de sua antiga senhora, mãe de Juliana, e entrar na Justiça para exigir que seu acordo de libertação, antes interrompido, fosse reafirmado (AHCSM - $2^{\circ}$ Ofício, Ações Cíveis, Códice 295, Auto 7134).

Na petição endereçada ao juiz no ano de 1808, o advogado de Quitéria revelou a motivação de Joaquim em desfazer o arranjo que antes lhe parecia favorável. Mesmo após as núpcias, ele quis continuar sua "ilícita amizade" com a crioula, que ao recusar mantê-la, provocou a ira do ex-amante e a destruição do seu papel de corte. Nesse aspecto, a experiência de Quitéria se aproxima da nossa primeira personagem, Josefa de Moraes: ambas tiveram a libertação facultada por seus amásios, continuaram a ser assediadas após a concessão da alforria ou da coartação e decidiram não mais ceder. Como resultado da recusa, tiveram que enfrentar a ira dos amantes enjeitados que investiram contra o estado de liberdade das crioulas, pelo qual uma e outra, por iniciativa própria ou em resposta, defenderam seus interesses na Justiça.

De sua parte, Joaquim contou uma história bem diferente em que a relação de intimidade entre ele e Quitéria é solenemente ignorada. Ao invés de rebater esse fato, ele aponta que sua reação

\footnotetext{
${ }^{12}$ A relação entre o trato ilícito e a coartação é explicitada no documento, embora não tenha sido esclarecido como uma coisa acabou por promover a outra.
} 
fora decorrente da infração das condições firmadas na coartação por parte da escrava, que se mudou para um lugar que distava duas léguas dos "limites consignados" por ele no acordo. Além disso, Joaquim afirmou que Quitéria não pagou as ditas 40 oitavas, tendo ele recebido um pouco mais da metade desse cálculo. Ao dirigir-se ao juiz, ele justificou sua atitude: "julguei que bastava ter ela arrebentado as condições do ajuste para ser apreendida como foi na dita paragem e que também o podia dispor como a dispus por entender assim ser a mesma justiça”. Considerou, portanto, ser sua vontade senhorial motivo de sobra para por termo à coartação, uma vez que a Coroa e suas instâncias representativas pouco ou nada interferiam na relação senhor-escravo, constituída no âmbito doméstico (Cunha, 1986:136-137).

Além das muitas dúvidas, as diferentes versões dos litigantes também suscitam muitas hipóteses. Podemos, por exemplo, entrever no relato do réu um certo desejo de controlar os passos da coartada, algo inclusive muito comum na relação entre outorgantes e beneficiados desse tipo de acordo de libertação, mas se levarmos em conta o "trato ilícito" mencionado pelo advogado de Quitéria, o desejo de controle parece aludir ao ciúme e talvez ao recalque que sentia o senhor rechaçado. Pensando ainda na possibilidade de terem sido amantes, podemos conjecturar diferentes motivações para o fim do relacionamento entre os dois. Com a aproximação das núpcias, Joaquim ou a família da noiva pode ter julgado de bom tom por fim à mancebia do noivo. A própria Quitéria pode ter arranjado uma maneira de se livrar das obrigações da alcova com o pretexto do matrimônio do amante, tendo na noiva ou em sua mãe aliadas para dar cabo ao seu intento. Não é possível saber o que se passou, porém, importa aqui ressaltar a possibilidade de Quitéria, uma vez coartada e vivendo como livre, sentir-se no direito de recusar as investidas do antigo amante, estando ciente ou não dos riscos advindos dessa atitude.

Além disso, dessa versão sobressai uma certa associação entre sua antiga mancebia com o senhor e o benefício da 
coartação, sugerindo que o novo dono resolveu testemunhar alguma gratidão pelos serviços íntimos prestados por Quitéria no passado, quando Joaquim se tornou seu senhor. Contudo, a relação de intimidade que teria lhe favorecido a conquista da liberdade também a levaria a uma situação muito pior que o seu anterior cativeiro. Ao resistir às novas investidas amorosas de Joaquim, agora seu senhor, Quitéria acabou vendo seu papel de corte virar pedaços, sendo levada para outro cativeiro e ainda ameaçada de ser negociada para fora da região.

A venda de Quitéria a outro senhor não a fez procurar a Justiça de imediato e se não surgisse a ameaça da venda para "outras paragens", talvez ela permanecesse no novo cativeiro indefinidamente. Seria essa experiência menos aviltante do que enfrentar ou ceder às perseguições daquele senhor amante? Não sabemos. O fato é que o medo de partir e de serem desfeitos os seus laços de sociabilidade, bem como sua rede de proteção, a fez recorrer àquela antiga senhora $e$ a abrir um processo contra seu ex-senhor e amásio, que lhe reduzira injustamente ao cativeiro ao efetuar sua venda, sem repassar ao comprador a coartação em curso para que lhe desse seguimento.

Ao que parece, mesmo tendo o processo sido abandonado após a retirada do réu para o Rio de Janeiro, podemos afirmar que a iniciativa de Quitéria foi, de alguma maneira, exitosa: ela conseguiu uma autorização do juiz que lhe assegurava viver em liberdade enquanto não fosse promulgada sentença que determinasse o seu estatuto jurídico (de escrava ou coartada). Esse desfecho, entretanto, não encobre a suscetibilidade da coartada diante do exercício de dominação senhorial. A história de Quitéria reforça a impressão de que as relações tomadas como ilícitas amorosas/sexuais -, fossem consensuais ou abusivas, poderiam tanto viabilizar a conquista da libertação, como intensificar a vulnerabilidade experimentada pelas mulheres de cor, assim sujeitas, muitas vezes, ao sabor dos tortuosos e instáveis caminhos da paixão. Vejamos outro exemplo dessa situação ambígua.

Trata-se do caso de Ana da Costa Barbalho que, apesar de ser forra e não ter o seu estatuto jurídico questionado, viu-se 
privada da liberdade ao ser presa por requerimento de um credor, Manuel da Costa Silva, devido à falta de recursos para pagar uma dívida decorrente da compra de uma negra, dada em troca de sua alforria. Em 8 de outubro de 1740,foi autuada uma ação de justificação ${ }^{13}$, por meio da qual Ana desejava comprovar "sua suma pobreza e miséria" para poder se livrar da "rigorosa prisão da cadeia", onde se encontrava "experimentando a cada instante as agonias da morte por falta de sustento para o alimento de seu corpo" (AHCSM - $2^{\circ}$ Ofício, Justificações, Códice 153, Auto 3394). A forra e suas testemunhas declararam que Manuel havia custeado a aquisição daquela escrava. Depois de alguns anos, contudo, passou a cobrar tal dívida; inquietava Ana com ameaças $e$ denúncias, tanto que ela já havia sido presa também por ordem da Real Intendência, graças às delações feitas nessa instância. ${ }^{14}$

A crioula protestava nos autos contra as perseguições afirmando que, no tempo da fiança, não tinha bem algum e disso todos sabiam, pois seu estado de pobreza era "fama pública". Ainda assim, Manuel se predispôs a ajudá-la naquela ocasião, entretanto, no presente, causava-lhe maior sofrimento. Ana tornara-se liberta e, apesar disso, manifestava ter ficado muito mais pobre, porque a liberdade lhe resultara na sua prisão. A reclusão a impedia de "viver da sua agência e trabalho" $e$, estando impossibilitada de se sustentar, dependia da caridade dos fiéis "que a socorria algumas vezes com alguns pratos de farinha". ${ }^{15}$ Em suma, a forra Ana, por causa de dificuldades

\footnotetext{
${ }^{13}$ A justificação era uma ação sumária, isto é, de praxe processual extraordinária. Seu caráter especial servia como um meio de constituir prova e reconhecê-la judicialmente, podendo ser utilizada para sustentar outros processos.

${ }^{14}$ Provavelmente, a ocorrência se deve ao não pagamento dos quintos, um imposto devido à Coroa portuguesa de $20 \%$ sobre o valor de qualquer metal ou pedra preciosa extraídos na colônia. A forma de cobrança desse imposto variou bastante e, no período em questão, parte dessa obrigação fiscal recaía sobre os forros residentes nas áreas de mineração.

${ }^{15}$ Nessa época, o sustento dos presos não ficava a cargo da administração pública e sim dos familiares dos presos, dos senhores (no caso dos escravos) ou de terceiros (como a Irmandade das Almas) que assistiam os encarcerados por benevolência.
} 
financeiras, foi impedida de vivenciar sua liberdade por quatro longos anos. Durante sua retenção na cadeia de Mariana, recebeu um tratamento pior do que quando esteve sob o julgo da escravidão: ficou sem mobilidade física, sem ração diária, sem vestuário e exposta à insalubridade da cela.

Durante a inquirição, a testemunha Jerônimo de Azevedo informa ao juiz que Ana vivia na casa de outro senhor e que foi instada por Manuel a mudar-se para sua casa, oferecendo-lhe benefícios, uma vida melhor e a alforria, ao que ela assentiu. Para conseguir a liberdade da cativa, comprou outra escrava dada em troca de modo a contentar o seu senhor. Feita a negociação, Ana passou a servi-lo de "portas adentro como de portas afora", além de ser "público e notório" que mantinham "trato ilícito". Passado um ano e meio, no entanto, Manuel começou a persegui-la, cobrando a dívida e colocando-a na cadeia, o que sugere um rompimento amoroso, tendo o fato lhe contrariado. Considerando esse testemunho, a relação que retirou Ana do cativeiro e lhe permitiu viver em estado de liberdade por um tempo, acabou por suspender o seu usufruto, uma vez que foi retida na cadeia a contento do ex-amante, quando a vida a dois chegou ao fim.

$\mathrm{O}$ caso amoroso e a insatisfação de Manuel não foram levados em conta no julgamento. Mas o seu conhecimento da "suma pobreza" de Ana quando ele se tornou seu credor, convenceu o juiz de que a forra deveria ser solta com a autorização do credor. Caso contrário, ele ficaria obrigado a custear a alimentação da presa. O que teria Manuel decidido? De início, ele embargou a sentença, mas seu recurso não foi aceito. Então lhe restaram como opções consentir o retorno à liberdade de Ana ou garantir seu sustento na cadeia. Percebe-se, com isso, que "viver sobre si" era prerrogativa de quem tinha autonomia para se deslocar e trabalhar. E tal autonomia nem sempre foi assegurada pela obtenção da alforria, pois, no caso das mulheres de cor, ela poderia ser estorvada pela ira de ex-companheiros, como aconteceu com Ana, ou mesmo pela escolha equivocada de um marido, conforme constatamos com o infortúnio vivido por Rita Botelho. 
Para essa, o passado de escravidão estava bem longe do seu presente de liberta bem-sucedida e sua trajetória parece, até certo ponto, uma narrativa de superação. Uma vez alforriada, a preta Rita conseguira acumular propriedades significativas que incluíam serviços minerais e escravos, além de ter encaminhado quase todos os filhos naturais. Era uma mulher madura quando decidiu comprar o escravo Fernando Botelho, preto Courano ${ }^{16}$ como ela, pensando em casá-lo com uma de suas filhas. No entanto, quando o trouxe para o convívio doméstico, Rita decidiu ela própria desposá-lo, concedendo-lhe, antes, a alforria. Bem mais velha que o sortudo mancebo, Rita adquiriu o status de mulher casada $e$ Fernando, por seu turno, tornou-se o administrador de todos os bens do casal, embora legalmente a posse dos bens pertencesse a ambos os cônjuges (Metcalf, 1989/90).

Daí por diante, a história foi tomando contornos que desagradavam, e muito, a preta forra. Fernando se meteu em concubinato com outras mulheres e passou a fustigar sua esposa. Ele a tratava:

\begin{abstract}
pior do que se fosse sua escrava, com muita fome e miséria, assim de sustento, como de vestuário e todo o mais necessário que nem 2 vinténs lhe dava para comprar sabão para lavar sua roupa; e tão rota e esfarrapada a trazia que quando ia à missa, ou confessar-se levava roupas emprestadas de sua filha (...). Isto sendo ela sua mulher, $e$ sócia conjugal, e senhora de todos os bens do casal.(AHCSM $-2^{\circ}$ Ofício, Ações Cíveis, Códice 303, Auto 7302, fl. 117v.).
\end{abstract}

Rita decidiu então iniciar um processo de divórcio. Para tanto, ela deixou a residência do casal, bem como todas as propriedades para colocar-se em depósito judicial, onde aguardaria por longos anos o julgamento de seu pedido de separação na Justiça Eclesiástica. Se de um lado, ela conseguiu escapar aos horrores da vida conjugal, ela viu, de outro, agravar

\footnotetext{
${ }^{16}$ Etnia africana, proveniente da África Ocidental, bastante presente em Mariana no século XVIII.
} 
sua miséria, pois ao ser colocada em guarda acabou impedida de "sair fora e usar de sua liberdade", impossibilitada de "tratar da vida e com trabalho lícito e honesto poder adquirir com que se pudesse sustentar e vestir". Podemos imaginar o que significou para essa mulher há muito libertada ver-se subjugada à guarda judicial por ordem do juiz eclesiástico e levada à casa do genro do marido algoz, onde ficou retida, sendo suprimido o usufruto de sua liberdade.

Para mover uma ação de divórcio ${ }^{17}$ contra o marido, a mulher devia ser colocada em depósito na casa de um terceiro, por vezes escolhido pelo marido, como no caso de Rita. Com isso pretendia-se ter sua honra vigiada, passando a viver em reclusão até que a decisão final fosse promulgada (Silva, 2001:82-83, Graham, 2005:93). Sem poder circular e empregar sua força de trabalho, sua condição de liberta e proprietária piorou a olhos vistos, tanto que reivindicou seu sustento também por intermediação da Justiça.

No Juízo secular ${ }^{18}$ da cidade de Mariana, Rita moveu, em 1765, um libelo de alimentos contra seu marido, exigindo dele que lhe pagasse alimentos e vestuário durante o período do depósito, até que saísse a decisão sobre o divórcio. Ela declarou sua idade avançada e a incapacidade para o trabalho como agravantes de sua miséria. $\mathrm{O}$ marido, porém, continuou a recusar seus pedidos de assistência, acusando-a de viver fugindo da guarda judicial. Disse tê-la visto andando pelo Morro de Santana sem se portar com o recato esperado de quem demandava o divórcio. Rita não respondeu às acusações de Fernando e seu silêncio pode ser indício de que realmente dava escapadelas ou de que conseguira

\footnotetext{
${ }^{17}$ Outros processos de divórcio promovidos nos séculos XVIII e XIX por africanas provenientes da Costa da Mina são encontrados em Farias (2015).

${ }^{18}$ A necessidade de Rita recorrer a dois tribunais diferentes - o Juízo Eclesiástico e o Juízo Geral da Cidade de Mariana - se deve às diferentes naturezas das matérias em disputa: naquele primeiro corria uma ação de divórcio, cabendo exclusivamente à Igreja deferir sobre o fim do voto sagrado, enquanto que no último tribunal, ela cuidou de reivindicar seu sustento, assunto que não dizia respeito aos dogmas religiosos.
} 
outro depositário, desvinculado do marido. De qualquer modo, o depósito judicial e a exigência de reclusão imposta à mulher casada e em processo de separação corroboraram a argumentação da Courana de que o divórcio causava-lhe transtornos a sua liberdade. Geralmente, um processo de dissolução do casamento restringia a atuação social de qualquer mulher nele envolvido. Porém, cabe aqui enfatizar que essa situação era vivida com maior apreensão por uma mulher forra, como Rita, que relacionava a autonomia de gerir sua vida à sua sobrevivência material (o que explica a necessidade de litigar pelo alimento e vestuário).

Ao refletir sobre o episódio, é comovente pensar que Rita, depois de promover a libertação de Fernando, teve a sua própria liberdade constrangida por conta do casamento frustrado com o ex-escravo. O fato de o marido ter sido alforriado pela esposa foi lembrado nos autos e assim foi incorporado à acusação principal: além da imputação de mau companheiro, Fernando foi também reputado como ingrato por deixar sua mulher e patrona sofrer grave carestia. Esse último argumento não foi empregado com a finalidade de revogar sua alforria, mas tão somente de reforçar a validade do pedido de sustento. Para tanto, o advogado de Rita teve o cuidado em explicitar que sua constituinte havia dado "carta de liberdade, com especial liberalidade gratuita, que nos ânimos rasteiros $e$ ingratos como o do réu nunca soubera reconhecer os benefícios". Tamanha era sua perversidade que, depois de casados, "devendo tratá-la (...) como sua única $e$ verdadeira consorte, reconhecendo-a ainda prescindindo do grande benefício que lhe fez vindo a ser sua senhora, e a pô-lo na liberdade, (...), chegou a fazê-lo pelo contrário, (...) amancebando-se com outras pretas solteiras".

Vivendo em uma sociedade escravista como a das Minas Gerais no período colonial, Rita alcançou a liberdade e uma sobrevivência material relativamente confortável. Não esperava ela, no entanto, que em sua maturidade se visse reduzida a uma outra escravidão, que desconhecera completamente até aquele momento: os constrangimentos legais e morais impostos às 
mulheres casadas, que, com frequência, podiam se tornar prisioneiras da vontade do marido, que, por sua vez, era amparado pelas leis seculares e religiosas, bem como pelos usos e costumes da época (Mott, 1988:18; Araújo, 1997:51). Desse novo cativeiro, Rita teve muito mais dificuldade em se desvencilhar.

Em comum com as demais personagens das contendas aqui analisadas, o gênero influenciou negativamente os destinos de Felícia, e consequentemente de Esméria, de Quitéria, Ana e Rita. $\mathrm{O}$ usufruto de suas liberdades lhes foi injustamente negado por diversas razões que se relacionavam à materialidade de seus corpos ou à sua condição de mulher. E queremos aqui ressaltar que esses processos judiciais, muito provavelmente, representam uma parcela ínfima dos conflitos que ocorreram naquela sociedade escravista envolvendo mulheres, pois apenas uma parte muito pequena deles deve ter chegado à Justiça e, desses, nem todos os registros foram conservados ao longo do tempo. No entanto, consideramos que são esses documentos representativos da vulnerabilidade que experimentaram as mulheres de cor residentes em Mariana colonial e, quiçá por outras de suas contemporâneas.

Em suma, nos casos aqui analisados, o gênero dessas mulheres por vezes auxiliou na conquista da alforria, mas também se mostrou um fator limitante da vida em liberdade. Felícia teve seu primeiro papel de corte rasgado porque ficou grávida (e por isso, Esméria nasceu em cativeiro), Quitéria viveu o mesmo por ter se recusado a ceder ao assédio sexual do antigo mancebo, Ana viu-se prisioneira numa execução de dívida porque seu patrocinador e amásio foi contrariado com o fim da relação amorosa, e Rita teve a liberdade constrangida quando iniciou um processo de divórcio na tentativa de escapar dos maus-tratos dispensados pelo marido. Em todos os exemplos, o fato de serem mulheres agravou situações existentes de opressão, características da tênue fronteira entre a escravidão e a liberdade. As coibições ou a perda da autonomia tiveram um peso ainda maior para as africanas e crioulas, visto que tal situação dificultava ou impedia 
sua própria manutenção material, como bem ilustraram as histórias de Ana e Rita.

Por fim, destacamos outra situação de ambiguidade característica das experiências de Felícia/Esméria, Quitéria, Ana e Rita. De suas narrativas, indiscutivelmente, sobressaem a vulnerabilidade $e$ a violência de gênero que sofreram em decorrência de uma gravidez, da exploração sexual ou mesmo da condição dependente de esposa. Ainda assim, não podemos desconsiderar o protagonismo dessas mulheres que recorreram à Justiça para defender seus interesses. Desse lugar ambíguo, misto de protagonismo e exploração, outras africanas $e$ crioulas puderam utilizar a condição desfavorável de mulher para fazer valer sua vontade, até mesmo numa arena pública de embates, como o tribunal de Mariana.

\section{B. As obrigações domésticas e o trabalho da alcova - libertas pelo trabalho}

Se de um lado o gênero agravou o estado de opressão de muitas mulheres de cor no termo de Mariana, por outro, ele se converteu em ferramenta poderosa para advogados, curadores $e$ juízes, empregada na defesa do estatuto de alforriadas e das condições de vida em liberdade dessas mesmas mulheres. De certo modo, a exploração de suas funções reprodutivas e sexuais, bem como outras atribuições de "esposas ou mães" foram, no caso das mulheres de cor, consideradas um tipo de trabalho $e$, como tal, lembradas de modo a beneficiá-las em disputas judiciais. O costumeiro trabalho invisível e não remunerado desempenhado por mulheres de todas as cores e categorias sociais no interior do lar tornou-se, em alguns casos, mercantilizado a fim de se evitar a reescravização, como veremos adiante. ${ }^{19}$

\footnotetext{
${ }^{19}$ Discussões interessantes sobre o trabalho não pago das mulheres no ambiente familiar e doméstico para os contextos anglo-saxão e europeu foram feitas em: Valenze (1995); Allen (2005); Davin (1978:87-139); Hill (1996); Prelinger (1987).
} 
De maneira geral, as senhoras brancas $e$ livres encarregavam-se de trabalhos domésticos fossem ricas ou pobres. Como mães, esposas ou filhas deveriam se ocupar com a administração do lar, o que incluía realizar -elas mesmas ou arregimentando e fiscalizando as escravas ou criadas - o cuidado com a casa, com as roupas, com os alimentos, com as compras, com as crianças, com os velhos e doentes de uma família. As esposas deveriam ainda cumprir as obrigações conjugais com o marido, das quais resultavam os filhos e, consequentemente, garantia a perpetuação da linhagem (Samara, 2006; Araújo, 2013). Embora fossem exaustivas e consumissem todas as horas de um dia, as tarefas domésticas eram difíceis de serem definidas quando desempenhadas pelas senhoras. Muitas vezes, nem sequer eram consideradas como trabalho. Diferentemente, as relações carnais com senhores ou patronos, o cuidado das crianças frutos dessas relações $e$ os demais cuidados de uma casa puderam ser minuciosamente quantificados e transformados em moeda de troca, em favor de crioulas e africanas.

O caso apresentado no início deste artigo da liberta Josefa de Moraes, ré de uma ação civil de reescravização, demonstra bem como os serviços sexuais a auxiliaram na obtenção $e$ manutenção da liberdade. Do "trato ilícito" com o senhor resultou sua alforria. Anos depois, quando resolveu dar um basta na concubinagem, foi ameaçada de perder o estatuto de mulher forra. No entanto, ela conseguiu apresentar carta de liberdade $e$ quebrou seu silêncio ao denunciar, diante do juiz, as investidas "imorais" do então ex-senhor, o que fez com que ele rapidamente encerrasse a contenda judicial. Talvez guiada por seu instinto de defesa, Josefa decidiu revelar publicamente o assédio do patrono, de modo a contrair a imagem de uma mulher frágil, perseguida $e$ explorada, inclusive (ou sobretudo) sexualmente, mas que decide por um basta à "imoralidade" e, em especial, à precariedade da liberdade até ali vivenciada. Desse modo, ela expôs publicamente seu algoz, dele se desvencilhando, possivelmente, em definitivo. Sua experiência, em muitos aspectos, nos remete à história de Maria Pinto de Távora. 
A crioula Maria saiu do cativeiro mais cedo, ainda criança, quando sua mãe era escrava de João Marques do Vale, que lhe concedeu alforria gratuita e incondicional. Apesar disso, cresceu na casa do patrono, vivendo e o servindo como se fosse sua escrava. Doze anos depois de liberta, sendo então uma jovem mulher, Maria Pinto de Távora decidiu ir "tratar de sua vida" $e$ deixou a casa de João do Vale para morar em casa de aluguel com seu amásio, e assim conseguir os meios de pagar seus "quintos reais", imposto que, na época, incidia sobre os libertos. Em outras palavras, aos 16 anos de idade, a crioula resolveu "viver sobre si" com um companheiro de sua escolha, deixando para trás os longos anos de serviço doméstico prestados ao exsenhor sem nenhuma remuneração.

Mesmo assim, a atitude de Maria Pinto de Távora enfureceu o patrono. Em 1743, três ou quatro meses depois que a liberta fora morar com o amásio, João Marques do Vale iniciou uma ação civil de reescravização para reduzir Maria ao cativeiro, alegando ingratidão e injúrias (AHCSM - $2^{\circ}$ Ofício, Ações Cíveis, Códice 246, Auto 6135). O autor do processo afirmou em Juízo que Maria tinha alforria condicional, devendo, portanto, servi-lo até sua morte. $\mathrm{E}$ para dar maior peso à transgressão, ele relatou casos de desobediência e ofensas por parte da liberta que o teria chamado de bêbado diante de testemunhas.

A partida da crioula, ao que sugere as testemunhas do processo, foi desde o começo litigiosa, pois, mais de uma vez, ambas as partes relataram agressões verbais $e$ físicas motivadas, talvez, pelo desejo da ex-escrava de partir. Ela, entretanto, parecia prever a ira do patrono, pois assim que deixou sua casa, tomou providências para registrar em cartório sua carta de liberdade. Quando foi intimada como ré do processo, preocupou-se em apresentar a alforria e rebater cada uma das acusações do exsenhor, tornando pública a espoliação de seu trabalho que sofrera por uma dúzia de anos. Na defesa apresentada ao juiz, seu advogado expôs 
que estando a Ré pela carta com plena liberdade, $e$ faculdade para ir para onde muito quisesse há mais de 12 anos, não só o não fez, mas antes todo este tempo até o presente esteve servindo ao Autor, e tratando-o com todo o respeito, e veneração sem lhe ser desobediente, nem ingrata em coisa alguma; e porque tinha a Ré de se vestir, sustentar, e pagar por sua pessoa os reais quintos, se saiu da companhia do Autor a tratar de sua vida, não obstante a repugnância deste que queria ter a Ré em sua casa como sua escrava, impedindo-lhe com violência 0 ir tratar de sua vida (AHCSM - $2^{\circ}$ Ofício, Ações Cíveis, Códice 246, Auto 6135, fl. 8).

Uma das testemunhas relatou que Maria Pinto de Távora já havia coabitado com outro homem por um período de 2 anos e meio, porém com a "autoridade" do patrono e "debaixo do seu domínio". Algo mudou dessa vez. Os autos sugerem que o litígio tenha sido motivado pelo fato de a crioula ter recusado a continuar prestando serviços ao ex-senhor, tendo fugido de sua casa. Isso é o que fica evidente em uma das inquirições das testemunhas. Antônio Rêgo "disse que sabe pelo ver e presenciar que 8 dias antes de sair a Ré de casa do Autor, castigando a esta por algumas [desenvolturas], [ela lhe advertiu] que se quisesse negras que as comprasse que ela não era cativa mas sim muito senhora de si".

Maria Pinto de Távora obviamente desejava pôr um fim à exploração de seu trabalho doméstico e consequente submissão ao patrono. Queria, enfim, fazer valer sua alforria para desfrutar da sua liberdade. Ao ser intimada para responder um processo de reescravização, ela conseguiu, com ajuda do advogado, provar merecer ser mantida em estado livre e o mais interessante: a crioula pediu ao juiz o rompimento dos laços de patronagem. ${ }^{20}$ Desvencilhada de qualquer relação de dependência com aquele que lhe concedera a alforria, Maria pretendia firmar sua

\footnotetext{
${ }^{20}$ Isso significa que por causa da perseguição sofrida, Maria Pinto de Távora quis que fosse desfeito ou invalidado o vínculo que a relacionada ao ex-senhor, que lhe concedera a alforria gratuita e a quem ela deveria, por isso, ser grata.
} 
autonomia, bem como se prevenir de futuras admoestações. No fim, ela alcançou sentença favorável, mantendo-se livre e fora da casa do patrono.

Não obstante a vitória, da sua trajetória ressalta o cotidiano de exploração que certamente foi igualmente vivenciado por outras meninas, libertas como ela que, a despeito do seu estatuto jurídico, permaneceram mais próximas de uma vida em cativeiro, sofrendo maus-tratos e realizando gratuitamente as funções domésticas na casa do ex-senhor em troca de alimentos, abrigo e proteção. No caso de Maria Pinto de Távora, no entanto, ela decidiu a certa altura de sua vida, gozar do estado de mulher alforriada, amparando-se na sua carta de liberdade para fazer valer sua vontade. Ao ser acusada no processo, reverteu a situação em seu favor, pondo um basta na exploração de seu trabalho e, possivelmente, em qualquer relação de dependência com o patrono. Sua experiência mostra como ela transformou a opressão vivida em moeda de troca, conseguindo se tornar, de fato, "muito senhora de si".

Mais surpreendente nesse aspecto é o caso de outra Maria e o argumento empenhado na Justiça para conservar sua liberdade. Tal como a personagem acima, a vendedora de pães, Maria Pinto, foi também chamada a responder um libelo de redução ao cativeiro, autuado em 1806 (AHCSM $-2^{\circ}$ Ofício, Justificações, Códice 162, Auto 3803). O autor desse processo, capitão Custódio José de Miranda, esperava vê-la novamente sob seu domínio senhorial. Para tanto, afirmou que Maria não quitou o preço da sua coartação e que o prazo dado para honrar tal acordo já havia finalizado. Como se não bastasse, declarou que a mesma desrespeitava a condição de não sair do termo de Mariana, "andando por onde quer[ia] como forra, sem obediência, ou reconhecimento de senhor". Essa versão senhorial foi contestada pela preta Mina, apesar das ameaças feitas pelo capitão Miranda, e dos atrasos na tramitação do processo decorrente da dificuldade de definir o paradeiro da ré.

De início, seu procurador e curador confirmou que Maria Pinto fora coartada por outro homem, seu então senhor, que 
depois vendeu sua coartação para o referido autor do processo de reescravização. E mais: detalhou que antes dessa negociação $e$ tendo autorização, a preta Mina já vivia na casa do capitão Miranda. Em sua companhia, "de portas adentro [ficava ela] servindo-o em todo o gênero de trabalho para depois abonar no seu coartamento o que ela vencesse". E ainda fazia e vendia pães no tabuleiro. Além de quitandeira e do serviço doméstico, Maria assumiu outra incumbência - o de amásia - e " "como senhora", se responsabilizava pelo governo da casa quando seu senhor $e$ amante se ausentava. Esse fato foi um dos que auxiliou o Dr. João de Souza Barradas a formar uma imagem de união consensual, por ele enfatizada muitas vezes nos autos. Nesse intento, destacou também o companheirismo e a fidelidade da preta Mina, sempre demonstrados em situações adversas. Além disso, o versado em leis revelou que dessa relação nasceram três crianças, todas "tidas e havidas" pela vizinhança como filhos do capitão Miranda, tanto assim que ele cuidava dos estudos de um deles, o menino.

Da casa e companhia do capitão Miranda, Maria Pinto teria saído ao tomar conhecimento do relacionamento dele com outra mulher. Mas algumas das testemunhas asseguraram que, na verdade, ela fora expulsa pelo senhor amásio, estando "pejada" e ao sentir as dores do parto numa ocasião em que o capitão julgava ser cedo para que fosse seu o rebento. Fosse como fosse, o certo é que o rompimento se deu de forma litigiosa. E como resultado desse desfecho e do temperamento do implicado, vez por outra Maria precisou se esconder para escapar da violência do capitão Miranda. Sua ira era tamanha que ele não se furtou de acionar a Justiça para questionar a liberdade desfrutada pela mulher, na tentativa de arrastá-la de volta ao cativeiro.

Conhecendo-o como, de fato, conhecia, é possível que Maria Pinto esperasse esse tipo de reação. E soubesse que o acordo firmado entre ela e o amante - de abater do seu corte o valor dos serviços prestados - era arriscado. Ela não tinha garantia de que o capitão Miranda faria a monetarização do trabalho dela obtido enquanto sua criada, depois de escrava coartada, sendo numa e noutra situação, sua amásia. Arelação amorosa poderia 
levá-lo a acreditar que o cuidado com a casa era sua obrigação. Mas o advogado da preta Mina pensava de forma diferente. Segundo o Dr. Barradas, o valor correspondente a todos os serviços domésticos executados por Maria deveria ser subtraído do preço firmado para sua libertação. Tendo em mente todo o tempo que ela permaneceu na casa do capitão Miranda, era de se convencer que nada mais lhe devia. E o mais surpreendente, para o curador estava claro que "ainda caso negado não estivesse pago com as referidas quantias, [deveria considerar] ter sido Maria sua amásia por tantos anos, de que também deve receber salário, sendo este devido às meretrizes". Sem nenhum constrangimento, o advogado monetarizou também o trato ilícito que o capitão manteve com a coartada, como se monetarizava os préstimos recebidos por uma prostituta.

Melhor dizendo, os diversos usos do corpo da mulher permitiram-lhe que alcançasse a liberdade e, em um tribunal colonial, esse argumento pareceu suficiente para convencer o juiz a manter Maria Pinto em estado livre. E de fato foi: na sentença final, a africana acabou absolvida da ação cível de reescravização. A ela foi facultado viver como mulher forra. É possível, contudo, que da liberdade não tenha conseguido desfrutar com total autonomia por causa do arrebatamento do ex-amásio. De todo modo, cabe aqui ressaltar a estratégia astuciosa do seu advogado, capaz de romper com os limites da moralidade e atribuir valoração ao trabalho carnal de uma mulher de cor, em vias de se libertar do cativeiro.

Nos casos de Josefa e das duas Marias, a exploração de seus corpos e de seu trabalho, fosse como administradoras do lar, mães ou amásias, foram contabilizados em seu favor, beneficiando-as nas disputas judiciais, em que moveram ou sofreram. Essas histórias revelam a possibilidade, ainda que remota, de conseguir transformar o abuso de seus corpos e de seu "trabalho de mulher" em instrumentos de luta em defesa de seus interesses. 


\section{Considerações finais}

O gênero definiu, em certa medida, a experiência e os destinos de algumas mulheres de cor, em Mariana Colonial, que viviam nas fronteiras nebulosas entre a escravidão $e$ a liberdade. Por meio das disputas judiciais nas quais tais mulheres se envolveram (ora como autoras, ora como rés), percebemos que a exploração de seus corpos e do trabalho "feminino" que desempenharam as tornaram mais vulneráveis, fossem elas livres, coartadas ou libertas. Algumas, contudo, conseguiram (tutoradas por advogados e/ou beneficiadas por juízes) tirar proveito da opressão vivida para conquistar seus direitos e fazer valer seus interesses. Ainda assim, seus percursos nos revelaram que nunca foram capazes de abandonar outro cativeiro, o de seus próprios corpos - ou melhor, do modo como eram vistos e tratados. Tanto que, por muitas vezes, precisaram resistir para escapar dos usos que senhores e patronos costumavam destinar a eles, de modo a evitar cenas como da epígrafe deste artigo, recriadas ficcionalmente no romance de Mayra Santos-Febres.

\section{Referências bibliográficas}

Algranti, Leila. Honradas e Devotas - Mulheres da Colônia: condição feminina nos conventos e recolhimentos do sudeste do Brasil, 17701822. Rio de Janeiro, José Olympio, 1993.

Allen, Ann Taylor. Feminism and Motherhood in Western Europe, 1890-1970: The Maternal Dilemma. Nova Iorque, Palgrave MacMillan, 2005.

ANAGOL, Padma. The Emergence of Feminism in India, 1850-1920. Londres, Ashgate Publishing, 2005.

ARAÚJO, Emanuel. A arte da sedução: sexualidade feminina na colônia. In: Del Priori, Mary (org.) História das Mulheres no Brasil. São Paulo, Editora Contexto, 2013, pp.45-77.

COLLeY, Linda. The Ordeal of Elizabeth Marsh. A Woman in World History. Nova Iorque, Pantheon Books, 2007. 
CunHA, Manuela Carneiro da. Sobre os silêncios da lei: lei costumeira e positiva nas alforrias de escravos no Brasil do século XIX. In: Antropologia do Brasil: mito, história, etnicidade. São Paulo, Brasiliense/Editora da Universidade de São Paulo, 1986, pp.123-144.

DAVIN, Anna. Imperialism and Motherhood. History Workshop, n5, Spring 1978, pp.87-139.

DAVIS, Natalie Zemon. Nas Margens. São Paulo, Companhia das Letras, 1997.

Del PRIORI, Mary. Ao sul do corpo: condição feminina, maternidades e mentalidade no Brasil Colônia. Rio de Janeiro/Brasília, José Olímpio/EdUnb, 1993.

DIAS, Maria Odila Silva. Quotidiano e Poder em São Paulo no século XIX. São Paulo, Brasiliense, 1995.

FARIA, Sheila de Castro. Sinhás pretas: acumulação de pecúlio e transmissão de bens de mulheres forras no sudeste escravista (sécs. XVIII-XIX). In: Fragoso, João; MATTOS; Hebe Maria; SILVA, Francisco Teixeira da (orgs.). Escritos sobre História e Educação. Homenagem à Maria Yeda Leite Linhares. Rio de Janeiro FAPERJ/Mauad, 2001, pp.289-329.

FARIAS, Juliana Barreto.Mercados Minas: africanos ocidentais na Praça do Mercado do Rio de Janeiro (1830-1890). Rio de Janeiro, Prefeitura do Rio de Janeiro/Arquivo Geral da Cidade, 2015.

FigueIREDO, Luciano Raposo de Almeida. $O$ avesso da memória: cotidiano e trabalho da mulher em Minas Gerais no século XVIII. Rio de Janeiro/Brasília, José Olympio/ Edunb, 1993.

FuRTADO, Júnia. Pérolas Negras: mulheres livres de cor no Distrito Diamantino. In: (org.). Diálogos oceânicos: Minas Gerais e as novas abordagens para uma história do Império Ultramarino Português. Belo Horizonte, Editora da UFMG, 2001, pp.81-121.

GONÇALVES, Andréa Lisly. As margens da liberdade: estudos sobre a prática de alforrias em Minas colonial e provincial. Belo Horizonte, Fino Traço/FAPEMIG, 2011.

GRAHAM, Sandra Lauderdale. Caetana diz não: História de mulheres da sociedade escravista brasileira. São Paulo, Companhia das Letras, 2005. 
HILl, Bridget. Servants: English Domestics in the Eighteenth Century. Oxford, Oxford University Press, 1996.

MACHADO, Maria Helena. Corpo, gênero e identidade no limiar da Abolição: a história de Benedicta Maria Albina da Ilha ou Ovídia, escrava (Sudeste, 1880). Afro-Ásia. Salvador, n 42, 2010, pp.157193.

METCALF, Alida. Mulheres e propriedade: filhas, esposas e viúvas em Santana de Parnaíba no século XVIII. Revista da SBPH. São Paulo, no 5, 1989/1990, pp.19-30.

MOTT, Maria Lúcia. Submissão e resistência: a mulher na luta contra a escravidão. São Paulo, Contexto, 1988.

NiCHOLSON, Linda. Interpretando o gênero. Revista de Estudos Feministas. vol.8, n², 2000, pp.9-43.

OliveIRA, Maria Inês Cortês de. O liberto: o seu mundo e outros, Salvador, 1790-1890. São Paulo, Corrupio, 1988.

PAIVA, Eduardo França. Escravidão e universo cultural na colônia: Minas Gerais, 1716-1789.Belo Horizonte, Editora da UFMG, 2001.

PERROT, Michelle. As mulheres ou o silêncio da História. Bauru, EDUSC, 2005.

PERROT, Michelle. Minha história das mulheres. São Paulo, Contexto, 2007.

PINHEIRO, Fernanda Domingos. Em defesa da liberdade: libertos e livres de cor nos tribunais do Antigo Regime português (Mariana e Lisboa, 1719-1820). Tese (Doutorado em História) Universidade Estadual de Campinas, Campinas, 2013.

PISCITELli, Adriana. Re-criando a (categoria) mulher?. Blog do Grupo de Pesquisa em Cultura e Gênero da Unesp. Marília, Unesp [http://www.culturaegenero.com.br/download/praticafeminina.pdf] acesso em: 20 jan. 2016.

Prelinger, Catherine. Charity, Challenge, and Change: Religious Dimensions of Mid-Nineteenth Century Women's Movement in Germany. Nova Iorque, Greenwood Press, 1987.

SAMARA, Eni de Mesquita. As mulheres, o poder e a familia. São Paulo, ANPUH/Marco Zero/FAPESP, 1989. 
. A Família Brasileira. São Paulo, Brasiliense, 2006.

SCOTT, Joan. Gênero: uma categoria útil de análise histórica. Educação e Realidade, Porto Alegre, vol. 20, n² 2, jul./dez., 1995, pp.71-99.

SiLva, Maria Beatriz Nizza da. História da familia no Brasil Colonial. Rio de Janeiro, Editora Nova Fronteira, 1998.

- Donas e plebeias na sociedade colonial. Lisboa, Editora Estampa, 2002.

SILVA, Marilda Santana da. Dignidade e transgressão: mulheres no Tribunal Eclesiástico em Minas Gerais (1748-1830). Campinas, Editora da Unicamp, 2001.

SOARES, Carlos Eugênio Líbano. Comércio, nação e gênero: as negras minas quitandeiras no Rio de Janeiro, 1835-1900. In: FRAGOSO, João; MATTOS; Hebe Maria; SILVA, Francisco Teixeira da (orgs.). Escritos sobre História e Educação. Homenagem à Maria Yeda Leite Linhares. Rio de Janeiro, FAPERJ/Mauad, 2001, pp.401-415.

SOIHET, Rachel. História, Mulheres, Gênero: contribuições para um debate. In: AGUIAR, Neuma. Gênero e Ciências Humanas:desafios às ciências desde a perspectiva das mulheres. Rio de Janeiro, Editora Rosa dos Tempos, 1997, pp.95-114.

SREENIVASAM, Ramya. Drudges, Dancing Girls, Concubines: Female slaves in Rajput Polity, 1500-1850. In: CHATTERJEe, I. J.; EATON, R. Slavery and South Asian History. Bloomington, Indiana, Indiana University Press, 2006, pp.136-161.

VALENZE, Deborah. The First Industrial Woman. Nova Iorque/Oxford, Oxford University Press, 1995.

WASHINGTON, Margaret. "From motives of delicacy": Sexuality and Morality in the narratives of Sojourner Truth and Harriet Jacobs. The Journal of African American History, Nova Orleans, vol. 92, $n^{\circ} 1$, 2007, pp.57-73.

WILDENTHAL, Lora. German Women for Empire, 1884-1945. Durham/Londres, Duke University Press, 2001. 